\title{
COMPREHENSIVE MODEL FOR UNDERSTANDING AND ENHANCING PRO- ENVIRONMENTAL PURCHASE BEHAVIOR: TOWARDS A CONCEPTUAL FRAMEWORK
}

\section{Converging Value-Belief-Norm Theory (VBN Theory) and the Theory of Planned Behavior (TPB)}

\author{
Achchuthan. $S^{*}$, Umanakenan. $R * * \&$ Kajenthiran. $K^{* * *}$ \\ * Lecturer in Commerce, University of Jaffna, Sri Lanka, achchu2009@gmail.com \\ ** Temporary Lecturer in Commerce, University of Jaffna, Sri Lanka, kenanratnam3@gmail.com \\ *** Postgraduate Student, University of Sri Jayewardenepura, Sri Lanka, kajentitans@gmail.com
}

\begin{abstract}
Inculcating pro-environmental purchase behavior is beneficial to both individuals and the society at large. The TPB has been generally applied to understand and examine pro-environmental purchase behavior. However, as the underpinnings of this theory are not adequate to understand the entire process of the development of pro-environmental purchase behavior, a more comprehensive theoretical framework is required. Combining the TPB with the VBN Theory provides such a comprehensive theoretical framework. Moreover, the presented model incorporates green perceived value and green Skepticism to predict pro-environmental purchase behavior strongly and to tackle the puzzle like green marketing myopia meticulously. It suggests that pro - environmental purchase behavior may be strongly predicted by pro-environmental purchase intention, green perceived value and green skepticism. The implications of this framework for theory and practice are discussed, as directions for future research, which would be of use to researchers and practitioners in the societal marketing field.
\end{abstract}

Keywords: Pro- Environmental Purchase Behavior, Value- Belief- Norm Theory, Theory of Planned Behavior

\subsection{Background}

Environmental problems such as global warming and pollution are identified and rationalized as more important global issues and make both individuals and organizations take measures for the preservation of the environment (Lobler, 2017). Environmental problems initiated the environmental issues with marketing, in which environmental management and marketing are integrated to focus on proenvironmental consumerism especially in the hyper competitive environment. Moreover,pro-environmental consum erism is focalized by researchers and practitioners as one of the newly-emerged and extensive concept in marketing, which encompasses all marketing activities that are carried out to motivate and strengthen favorable environmental attitudes, purchase intentions and behaviors towards eco-friendly products (Nelson, 2016). Interestingly, to advance a country's green revolution, scholars assert that the role of consumers is essential. This 
assertion is supported by the evidence that environmental degradation has been brought about by the consumption activities (Zhu \& Sarkis, 2016). Hence, to better understand the environmental movement of a particular nation, an examination of how consumers view and feel about ecological issues, and how they behave accordingly, serves as a good starting point. In line with the above facts, scholars in the Asian and developing countries document that, absence of green consumption is the crucial issue to make the nations green (Kumar et al., 2017; Liobikienè et al., 2017).

Sociology, Environmental Studies and Human Behavior are combined to give the new insights to the marketing paradigm in the standpoint of pro-environmental consumerism. Further, the concept as the pro-environmental consumerism is placed as the prominent research theme to find out the cues in developing countries and developed countries (Grimmer\& Woolley, 2014). Scholars in the proenvironmental behavior document that, studies are necessary to explore the new insights into the developing countries from the studies in this region seem to be a complicated one. Meanwhile, cultural value orientations in developing countries are different from those of developed countries (Bailey et al., 2016). Moreover, these days, environmental issues are viewed as the pressing problems among many Consumers, Policy Makers, Environmentalists, Government and NonGovernmental bodies. This is why, the practice of green marketing and the theme as "Going green" are extending to the Asian region where environmental threats are damaging the welfare of the society and citizens (D'Souza et al., 2015).

In Asian Region, newly industrialized Countries like Malaysia, China, and Singapore, etc. started to initiate the environmental issues as the major concern in the recent decade. Meanwhile, its environment quality legs far behind when compared to the developed countries. Further, D'Souza et al. (2015) and Bailey et al. (2016) note that, government policies and business strategies in many Asian countries are being reshaped to give more consideration for long-term sustainable development including environmental protection. Moreover, Asian Region aspires to motivate people to choose healthy/organic food products, reduce pollution through new regulations and involve in less carbon emission policy. Based on the overall picture of the green issues and its trend in the Asian region, empirical studies on green consumption are much needed to get the new cues. Based on the above underpinnings, researchers intend to develop the integrated model for understanding and enhancing proenvironmental purchase behavior.

\subsection{Underpinning Theories}

This aspect is directed towards theories and approaches of green marketing, consumer behavior and pro-environmental purchase intention \& behavior, which give basic direction to construct the model. Importantly, this fragment explicates 1) Model of Consumer Behavior, which is investigated in the light of the marketing environment, buyers' characteristics and buyer's decision process to understand the consumerism. 2) Theory of Reasoned 
Action and Planned Behavior, which is aimed at explaining the value - attitudeintention - behavior relationship with respect to consumer behavioral research. Further, TPB elucidates the facts that high accuracy from attitudes toward the behavior, subjective norms and perceived behavioral control are able to predict the intentions to perform behaviors of different kinds; and these intentions together with perceptions of behavioral control account for considerable variance in actual behavior. 3) Finally, Altruism and Pro-Social Behavioral Theory are utilized to explicate the facts that the personal norm is a key determinant that bridges the value action gap as a moral obligation go beyond the behavioral intention and activates the actual behavior.

\subsection{Theory of Consumer Behavior: Marketing Perspective}

Stakeholder theory covers and investigates the parties who are interested in a particular organization. Stakeholder theory is broad as far as the theoretical and practical scenarios are concerned. Even though, it highlights that customers in the interested parties should be considered as the key element in the business activities and its success. Further, customers are also considered and recognized as the most valuable assets in the world of marketing. Marketing should identify and satisfy the target customers' needs and wants. As a result, the field of consumer behavior takes the important place among scholars and industrialists to study the way how individuals, groups and organizations select, buy, use and dispose of goods, services, ideas or experiences to satisfy their needs and desires.
Understanding consumer behavior is complex; it depends on various factors as (1) Marketing Stimuli (Product, price, place and promotion), (2) Other Stimuli (Economic, Technological, Political and Environmental factors), (3) Personal and psychological factors of buyer's (Personality, Learning, Motivation etc.). Those factors directly and indirectly influence the buyer decision making process. Problem recognition, information search, evaluation of alternatives and post purchase behavior are chosen to explain the complex consumer behavior model (Kotler \& Armstrong, 2013).

Based on the aforementioned viewpoints, this study investigates the factors influencing purchase behavioral intention in the light of green consumerism. Studies on green consumerism differ from general consumerism. Generally, the cost and benefits of the products and services are assessed by consumers. Individual benefits are considered as the key fact, while, cost also is associated with benefits to measure the customer value creation. In contrast, both individual and social benefits relating to environmental concern \& attitude, nature \& its future and resource allocation are renowned as the key elements in the green consumerism (Kotler \& Keller, 2006; McCarty \& Shrum, 2001). In line with this, proenvironmental purchase behavior is investigated in this study, which gives the different path or direction to focus on the social benefits and long term sustainability through the green consumerism.

\subsection{Theory of Planned Behavior}

In 1991, Ajzen framed the TPB as the extended model, which was developed 
as the extension of the theory of reasoned action. Theory explains that high accuracy from attitudes toward the behavior, subjective norms and perceived behavioral control are able to predict the intentions to perform behaviors of different kinds; and these intentions, together with perceptions of behavioral control, account for considerable variance in actual behavior. The TPB (Ajzen, 1991) presents intention dependent upon three factors: (1) The individual's attitude toward the behavior (2) Subjective norm and (3) Perceived behavioral control.

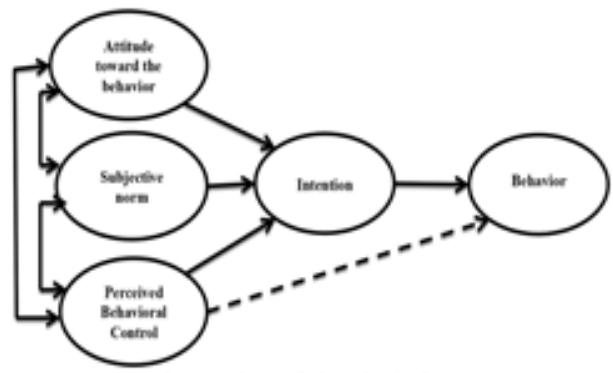

Figure 1: Theory of Planned Behavior Source: Ajzen (1991), Theory of Planned Behavior

\section{Attitude}

Attitude towards performing behavior refers to perceptions of personal desirability to perform the behavior (Ajzen, 1991). It depends on the expectations and beliefs about the personal impacts of outcomes resulting from the behavior.

\section{Subjective Norm}

The TPB holds that subjective norm is a function of beliefs. If a person believes that his or her referents think that behavior should be performed, then the subjective norm will influence his or her intention to perform that particular behavior. The referents here refer to a group of people who are close to the individual, for instance family, peers, spouse, close friend, teachers and anyone considered important in the individual's life (Ajzen, 1991).

\section{Perceived Behavior Control}

Perceived Behavior Control reflects the perceived ability to execute target behavior (Ajzen, 1991). It relates to an individual's perception on the degree of easiness and difficulties in performing such behavior, and it is assumed to reflect past experience as well as anticipated obstacles (Ajzen \& Driver, 1992). This construct is affected by perceptions of access to necessary skills, resources and opportunities to perform the behavior. If an individual feels that he or she has control over the situational factors, he or she may develop the intention to perform the particular behavior. On the other hand, if an individual does not have control over the circumstances, he or she may not have any or low intention to perform the particular behavior.

\subsection{Theory of Planned Behavior and Pro-environmental purchase behavior}

TPB has been used in numerous studies in consumer behavior towards green issues (Arvola et al., 2008; Aertsens et al., 2009 ; Albayrak et al., 2013; Chen \& Tung, 2014; Nguyen et al., 2016; Yadav \& Pathak,2016; Alcock, et al., 2017; Grimmer \& Miles, 2017). In this way, based on the TPB, Moe (2007), Aertsens et al. (2009) and Nguyen et al. (2016) focus the study on sustainability; the study defines green purchase intention as "selectively choosing products with less environmental impact when purchasing 
goods", which means the green consumer tends to purchase green product to reduce the harmful effects on the environment. In addition, green purchase intention is defined as the probability and willingness of a person, which are directed to purchase the eco-friendly products over non - green products in their purchase decisions. Further than, Beckford et al. (2010), Yadav and Pathak (2016) and Alcock, et al. (2017) explore that green purchase intention is a considerable predictor of purchase behavior towards green consumerism; it denotes that purchase intention is positively associated with the probability of a customer decision that the customer will buy the green products. In a supportive way, Chan (2001) and Grimmer and Miles (2017) point out that environmental concern is highly associated with intention, which will lead to behavior towards green aspects finally.

In contrast, study findings of Ohtomo and Hirose (2007), Chaplin and Wyton (2014) and Caruana et al. (2016) reveal some interesting aspects that green consumer behavior is not influenced by the intention; in other words, green purchase intention does not provide the path for behavior. A person who holds the environmental concern and knowledge does not put the effort to purchase green products; such issues are called or named as the value - action gap. It means that, although the customers show the intention to purchase the green product, they are not in a position to exercise the actual performance. Several factors on valueaction gap as individuality, responsibility and practicality are identified and discussed by Blake (1999); Chaplin and Wyton (2014) and Warde (2017) .In this context, individual barriers are those that are person-specific related to that individual's attitudes and beliefs. An individual who is not interested in environmental issues or feels that other topics require more attention is less likely to adopt an environmental behavior. The second is the responsibility; it is the common barrier to action regarding environmental issues. Many individuals feel that one person should not be responsible for the health of the environment or that one person's action cannot make a difference, leading many people to not adopt an environmental behavior. The final barrier practicality, represents constraints that would prevent an individual from taking action. By feeling that they lack time, money, or information, many individuals feel unable to adopt an environmental behavior, even if they have a positive attitude towards it. In the supportive view, several research findings proved the value- action gap and its consequences in the green consumerism (Chaplin \& Wyton, 2014; Martin, \& Väistö, 2016; Caruana et al., 2016; Warde, 2017). Therefore, researchers in this work mainly concentrate on the main puzzle as Valueaction - gap in green consumerism to enhance the predictability of the proenvironmental purchase behavior.

\subsection{Theory of Altruism and Pro-Social Behavior}

Model of altruism and pro-social behavior is considered as the prominent conceptual framework to discuss the pro- environmental behavior. In which, "Pro-Social" is defined as "Voluntary intentional behavior that results in benefits for others, the motive is unspecified and may be positive, negative or both" (Eisenberg \& Miller, 1987). In this 
view, altruism is a subset of pro-social behavior and scholars frame their models and assumptions based on theories of altruism claiming altruism as a key feature for supporting pro-environmental behavior (Samarasinghe, 2012). Further, this theoretical framework has two assumptions: 1) A Person with a strong selfish and competitive orientation are less likely to resort to pro - environmental behavior (Pro-self); 2) People who satisfy their personal needs are more likely to act pro-environmental behavior, because they have more resources (time, money and energy) to care about larger proenvironmental issues (Samarasinghe, 2012 ).

Under the Altruism and Pro-Social Behavior Theories, two models as Norm Activation Theory of Altruistic Behavior" (Schwartz, 1977) and "Value-BeliefsNorm Theory - VBN Theory (Stern, 2000) are discussed.

\subsection{Norm-Activation Theory of Altruistic Behavior}

Universal value system, which scrutinizes the behavior as a function of beliefs about the consequences of actions and norms about personal responsibility to undertake a specific action in response is introduced in this theory (Schwartz, 1977). This theory postulates that awareness of consequences, awareness of needs, situational responsibility, efficacy, ability and denial of responsibility are the determinants of personal norm, which in turn activate the behavior. Activation of a "Personal Norm" is viewed as the important antecedent of pro - environmental behavior. When the individual perceives that unfavorable event is occurred with individual wellbeings, others well - beings and nature through environmentally harmful events, activation of norms takes place. In which, personal norm is experienced and considered as the moral obligation to protect the environment from the environmental threats and pollution. Thus, this theory explicates that the individual's general and environmental value orientations influence the personal norms.

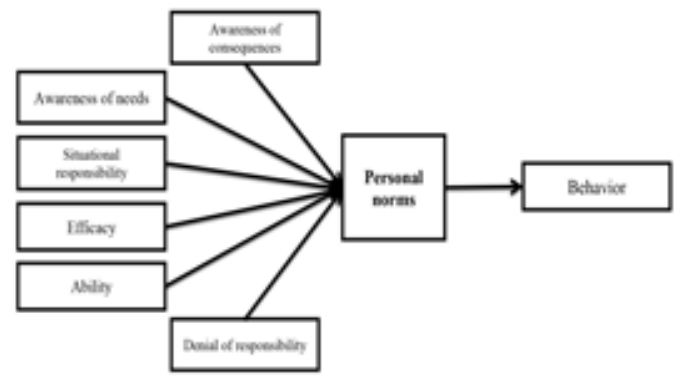

Figure 2: Norm-Activation Theory of Altruistic Behavior

Source: Schwartz, 1977, Norm-Activation Theory of Altruistic Behavior

\subsection{Value-Beliefs - Norm Theory-VBN Theory}

Value - Beliefs - Norm Theory - VBN Theory was framed by Stern (2000). This model is an extension of the norm - activation theory. This value - belief norm theory is originally an explanation of altruistic behavior but specially is extended to pro-environmental behavior (Samarasinghe, 2012 ).According to the previous theories as value theory (Schwartz, 1992), norm-activation theory (Schwartz, 1977) and the new ecological paradigm (Dunlap et al., 2000), Stern (2000) documents that personal norm is a key determinant that bridges the value action gap as a moral obligation and activates the actual behavior, in which human value orientation is adopted. 
And values are categorized into three constructs as 1) egoistic orientation, which is concerned with the removal of suffering and harm from oneself; 2) altruistic orientation, which is concerned as the social orientation; 3) biospheric orientation which is concerned with the removal of destruction and suffering in the non-human world. Those constructs are prerequisites for attitude formation and norms that determine actual behavior.

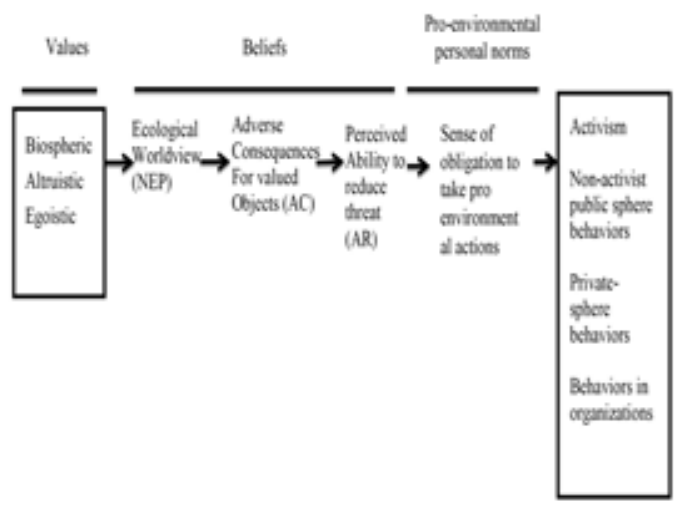

Figure 3: Value - Beliefs - Norm Theory - VBN Theory

Source: Stern (2000), Value - Beliefs - Norm Theory - VBN Theory

\subsection{Development of Conceptual Framework}

Drawing on the critical review of TPB and VBN Theory with the customer centric concept as green perceived value, this work proposes the comprehensive model to predict and enhance the proenvironmental purchase intention and behavior. Researchers in this work converge the TPB and VBN Theory to enhance the predictability of proenvironmental purchase behavior. The main underpinning reason for merging the two theories is to enhance the predictability of pro-environmental purchase intention and behavior. In general, such proenvironmental intention or behavior is activated by either pro-social or selfinterest motives. Researchers who view individuals' environmentally responsible intention and behavior as being stimulated by pro-social motives generally utilize the VBN Theory, while researchers who consider eco-friendly intention and behavior as self-interest motives mostly rely on rational-choice models such as TPB (Wei et al., 2017 ; Lin et al., 2017).

Existing research findings in green consumerism using TPB revealed that the attitude towards behavior, subjective norm and perceived behavioral control influence the purchase intention towards eco- friendly products. Meanwhile, proenvironmental personal norm also well predicts the green purchase intention in the light of VBN Theory (Arvola et al., 2008; Aertsens et al., 2009; Albayrak et al., 2013 ; Chen \& Tung, 2014; Nguyen et al., 2016; Yadav \& Pathak,2016; Alcock, et al., 2017; Grimmer \& Miles, 2017). However, researchers in the field of green consumerism mainly concentrated their research works using either the TPB or the VBN Theory. Moreover, personal norm is the unique factor, which activates the obligation of individuals towards eco- friendly purchase than the three unique factors as attitude towards behavior, subjective norm and perceived behavioral control extracted from TPB (Thøgersen \& Ölander, 2006; PickettBaker \& Ozaki, 2008; Klöckner, 2013). Therefore, researchers intend to create the hybrid model by incorporating the factors like attitude towards behavior, subjective norm and perceived behavioral control mined from the TPB and personal norm extracted from the VBN Theory. Hope, this model well predicts proenvironmental purchase intention and 
behavior than the factors or antecedents extracted from single theory.

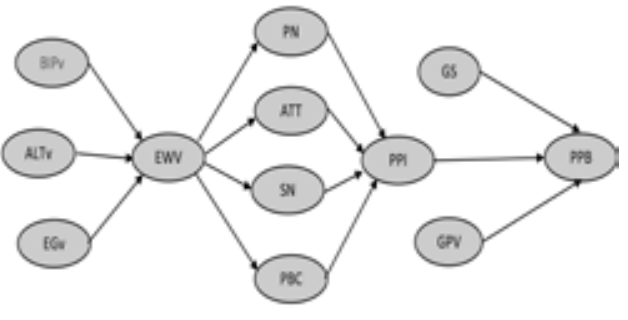

Figure 4: Integrated Model of Pro- Environmental Purchase Behavior

Where:

$\begin{array}{ll}\text { BIPv } & : \text { Biospheric Value } \\ \text { PBC } & : \text { Perceived Behavioral Control } \\ \text { ALTV } & : \text { Altruistic Value } \\ \text { GPV } & : \text { Green Perceived Value } \\ \text { EGv } & : \text { Egoistic Value } \\ \text { PPI } & : \text { Pro- Environmental Purchase } \\ & \text { intention } \\ \text { EWV } & : \text { Ecological World View } \\ \text { PPB } & : \text { Pro- Environmental Purchase } \\ & \text { Behaviour } \\ \text { PN } & : \text { Pro- environmental Personal Norm } \\ \text { GS } & : \text { Green Skepticism } \\ \text { ATT } & : \text { Attitudes towards Behavior } \\ \text { SN } & : \text { Subjective Norms }\end{array}$

Surprisingly, pervious researchers in the area of green consumerism predominantly ground the works using the factors with related to the pro- environmental aspects. It further implies that researchers failed and missed to distillate the main theme as the green perceived value. Generally, the green perceived value is the core fact in customer centric aspect, in which functional and emotional benefits are investigated with environmental concern (Chen \& Chang, 2012; Chen, 2013) But, existing research findings miscarried to find the cues that the extent to which actual performance of the products along with environmental concern influence on pro- environmental intention and behavior. This disparity is called as green marketing myopia (Ottman et al., 2006). On the whole, above discussion directs the researchers to construct the comprehensive model. The presented model might resolve the main puzzles in green consumerism literatures as value - action gap and green marketing myopia. Green marketing myopia might be resolved by incorporating the green perceived value into the model as the antecedent variable of the proenvironmental purchase behavior. It suggests that people who concentrate on the actual performance of the products along with the environmental quality of the products likely prefer to purchase the green products than the traditional one. Value - action gap might also be resolved by enhancing the predictability of purchase intention through converging the TPB and the VBN Theory. Further than, green skepticism also might influence the predictability of the proenvironmental purchase behavior in the dynamic environment.

To this end, incorporating the various pro - environmental oriented factors extracted from TPB and VBN theory, customer centric variable as green perceived value and green skepticism make this model comprehensive one.

\subsection{Underpinning Variables in the proposed model}

Biospheric value, Altruistic value, Egoistic value and Ecological World View

VBN Theory assumes a hierarchical model where individual value orientations directly influence beliefs, and thereby 
attitudes and behavior by filtering the information to be evaluated. More detailed analysis of each of the variables considered in this theory reveals, on the first level, value orientations, which are classified as biospheric, social or altruistic and egocentric or selfish (LópezMosquera \& Sánchez, 2012; Han et al., 2010). Biospheric value is linked to the nature and biosphere; altruistic value is concerned with the welfare of others; and egoistic value emphasizes maximizing individuals' benefits.

In VBN Theory, the role of value and ecological worldview is emphasized. Ecological worldview (New ecological paradigm) indicates "the propensity to take actions with pro-environmental intent". In this context, value orientations such as biospheric, altruistic, and egoistic values are directly related to the ecological worldview. Unlike egoistic values that lose the environmental worldview, biospheric and altruistic values are likely to hold it. (López-Mosquera \& Sánchez, 2012; Han, Hsu \& Sheu, 2010). Above arguments strain that biospheric, social or altruistic and egocentric or selfish value influence on ecological worldview.

The propensity to take action with pro- environmental intent taps the consumers' mind pleasantly to evaluate the environmental aspects and perceive the moral responsibility to take care of the environment from the harmful effects. Moreover, the propensity to take action with pro- environmental intent enhances the consumers' confidence to act as the residents who concern about the environment. To this end, pro- environmental intent directs the people to encourage others to consider the environmental concern also.

Therefore, the following hypotheses are formulated.

$\mathrm{H}_{1:}$ Biospheric value influences the ecological world view

$\mathrm{H}_{2:}$ Altruistic value influences the ecological world view

$\mathrm{H}_{3:}$ Egoistic value influences the ecological world view

$\mathrm{H}_{4:}$ Ecological world view influences the attitude towards behavior

$\mathrm{H}_{5:}$ Ecological world view influences the subjective norms

$\mathrm{H}_{6:}$ Ecological world view influences the perceived behavioral control

$\mathrm{H}_{7:}$ Ecological world view influences the personal norms

\section{Attitudes towards behavior, Subjective norms, Perceived behavioral Control and Personal norms}

As we earlier pointed out, three important variables like attitudes towards behavior, subjective norm and perceived behavioral control are mined from TPB. Personal norm is extracted from VBN Theory. Though, the extraction of those underpinning factors ensures their unique character and the association between pro- environmental purchase intention and behavior. In this way, attitude toward the behavior refers to "the degree to which a person has a favorable or unfavorable evaluation or appraisal of the behavior in question". It further implies that, "Individuals value judgment of environmental protection, which taps the individuals' cognitive assessment of 
the value of environmental protection" (Lee, 2008). Environmental attitude is identified as an important predictor of the green purchase intention and behavior in Western and Asian literature (Crosby et al.,1981; Jobber, 2007; Mostafa, 2007; Lee, 2008; Mei et al.,2012; Arttachariya, 2012).

Subjective norm is whether an action should or should not be performed by respondent in a referents' point of view. Referents could be parents, friends, neighbors, relations .It denotes to the perceived social pressure to perform or not to perform the behavior. Several studies have been conducted on the theme that subjective norm is the significant predictor variable of pro- environmental purchase intention and behavior. And, the relationship between those variables are proved and documented in the Western and South Asian literature (De Leon \& Fuqua, 1995; Lee, 2008; Baker \& Ozaki, 2008). Further, Perceived behavioral control in pro- environmental fact is the judgment of an individual about the way and the extent of the environmental effects of his or her behavior. Further, it differs from person to person, because of the dissimilarity in individuals' personal knowledge and life experience. Some people have thoughts that, their actions hold evolutionary results whereas others may have little confidence in their abilities to make any difference. In line with this, the relationship between perceived behavioral control and proenvironmental purchase intention and behavior is documented and supported by previous Western and Asian empirical works (Ellen et al., 1991; Lee \& Holden, 1999; Kim \& Choi, 2005; Chen, 2007; Lee, 2008).
The VBN Theory assumes that one's eco-friendly intention and behavior is determined by pro-environmental personal norms; and these personal norms are activated by the sequential process of values / ecological worldview ( Stren, 2000). Overall, above discussions pinpoint that, attitudes towards behavior, subjective norm and perceived behavioral control extracted from the theory of planned behavior and personal norm mined from value- belief-norm theory influence the pro-environmental purchase intention and behavior. Researchers in this work have an intention to develop the hybrid model to predict the pro- environmental purchase behavior. Hope, the integration of those mentioned variables ensure the predictability of the pro- environmental purchase intention and behavior. Hence, the following hypotheses are formulated.

$\mathrm{H}_{8:}$ Attitudes towards behavior influences the pro- environmental purchase intention

$\mathrm{H}_{9}$ Subjective norms influences the proenvironmental purchase intention

$\mathrm{H}_{10:}$ Perceived behavioral Control influences the pro- environmental purchase intention

$\mathrm{H}_{11:}$ Personal norms influences the proenvironmental purchase intention

\section{Pro-Environmental Purchase intention, Green Skepticism, Green Perceived Value and Pro-Environmental Purchase behavior}

Behavioral intention can be described as "an indication of how hard people are willing to try, of how much of an effort they are planning to exert, in order to 
perform the behavior". According to the above facts, attitudes towards behavior, subjective norm, perceived behavioral control and personal norm influence the pro-environmental purchase intention, which in turn lead to pro- environmental purchase behavior. However, there is a gap between purchase intention and behavior due to the barriers in terms of individuality, responsibility and practicality. We, researchers in this work though that, green perceived value might bridge this gap due to its applicability in the customer - centric research. Green perceived value is well defined as "a consumer's overall appraisal of the net benefit of a product or service between what is received and what is given based on the consumer's environmental desires, sustainable expectations, and green needs" (Koller et al., 2011; Chen, \& Chang, 2012; Chen, 2013). It further implies that, pro-environmental purchase intention strongly leads to behavior among the customers who enjoy the actual performance of the products along with the high environmental quality. Further, researchers in this work anticipate to incorporate the green skepticism and its role in the value- action gap (do Paço \& Reis, 2012; Matthes \& Wonneberger, 2014). It further signifies that doubts about the green products in consumers' mindset make them to purchase ecofriendly products less and less, even if they have favorable environmental attitude and concern. Therefore, the following hypotheses are formulated.

$\mathrm{H}_{12:}$ Pro- environmental purchase intention influences the proenvironmental purchase behavior

$\mathrm{H}_{13 \text { : }}$ Green perceived value influences the pro- environmental purchase behavior
$\mathrm{H}_{14}$ : Green Skepticism influences the pro- environmental purchase behavior

\subsection{Implication for Theory and Practice}

Researchers already paid attention to reveal the extent to which environmental attitude and other pro-environmental related factors like subjective norms, perceived behavioral control and personal norms influence on pro-environmental purchase intention and behavior (Wei et al., 2017; Lin et al., 2017). Due to this, this way of research findings miscarry to take the real fact behind the green perceived value of the products and its influence on the purchase behavior. In this context, the green perceived value of the products makes the customers satisfied and concern about the environment also. It further infers that the studies related to pro-environmental purchase behavior in the light of pro-environmental oriented factors consider the environmental concern only not the green perceived value (Chen \& Chang, 2012; Chen, 2013).

This issue is called as green marketing myopia. Green marketing must satisfy two objectives: improved environmental quality and customer satisfaction. Misjudging either or overemphasizing the former at the expense of the latter can be termed "green marketing myopia." To this end, the green perceived value resolves the main puzzle as green marketing myopia by incorporating the facts like performance of the products and environmental concern. Here, the perceived performance of the products 
along with the perceived environmental quality of the products make the customers satisfied as the people who concern about both the environmental issues and actual performance of the products (Ottman et al., 2006). Moreover, consumers in this era have some doubts on the green claims of the organization. Sceptics entertain doubts about what other people say or do. But he or she can be convinced when proofs are shown. Skepticism is a cognitive reaction that varies in accordance with the occasion and the content of the communication. In line with the above arguments, doubt about the green claims of the products makes confusion to prefer the green products. This issue is called as green skepticism and ignored by marketing academics and practitioners. Importantly, green skepticism makes a major barrier to prefer or like the green products. Therefore, by incorporating pro-environmental factors, green perceived value and green skepticism in a single study may resolve the major puzzles in the green marketing field as value- action gap and green marketing myopia.

\subsection{Limitation and Future Research Direction}

This work concentrates on the conceptual development towards proenvironmental purchase intention and behavior. Here, researchers utilized the two main theories as TPB and VBN theory to construct the conceptual model to predict the pro- environmental purchase behavior. Future scholars in this field may focus on various theories to predict the purchase behavior related with green products. This study didn't test the model through the appropriate techniques to come to the generalization. Therefore, future researchers may take these facts to consider the different market segments in terms of geographical, demographical and psychographic aspects to check the level of generalization and the validity of the model.

\subsection{Conclusion}

Resources are limited and human wants are unlimited in the planet. Therefore, it is important for the marketers to utilize the resources effectively and efficiently without having waste as well as to achieve the organizational objectives (Lobler, 2017). In this context, Social, cultural, economic and psychological factors and its influence on sustainable consumer behavior take the prominent place in marketing research. Based on the above point, there is a paucity of research works on the green issues in the social research and its practices. In recent years, the topic of sustainable consumerism has been captured and initiated by researchers and practitioners with unprecedented attention in both developed and emerging countries. In this standpoint, such understanding or finding helps Government officials, educators, business organizations and policy makers in the Asian Region and other countries in globalized level, to enhance the sustainable aspects with consumption issues among public and hence reduce the harmful effect on the environment, which, in turn develop the sustainable aspects in the long term perspective. 


\section{References}

1. Aertsens, J., Verbeke, W., Mondelaers, K., \& Van Huylenbroeck, G. (2009). Personal determinants of organic food consumption: a review. British Food Journal, 111(10), 1140-1167.

2. Ajzen, I. (1991). The theory of planned behavior. Organizational Behavior and Human Decision Processes, 50, 179-211.

3. Ajzen, I., \& Driver, B. L. (1992). Application of the theory of planned behavior to leisure choice: Journal of Leisure Research, 24(3), 207-224.

4. Albayrak, T., Aksoy, Ş., \& Caber, M. (2013). The effect of environmental concern and scepticism on green purchase behaviour. Marketing Intelligence \& Planning, 31(1), 27-39.

5. Alcock, I., White, M. P., Taylor, T., Coldwell, D. F., Gribble, M. O., Evans, K. L., ... \& Fleming, L. E. (2017). 'Green' on the ground but not in the air: Pro-environmental attitudes are related to household behaviours but not discretionary air travel. Global Environmental Change, 42, 136-147.

6. Arttachariya, P. (2012). Environmentalism and Green Purchasing Behavior: A Study on Graduate Students in Bangkok, Thailand. Assumption University, Thai Land.

7. Arvola, A., Vassallo, M., Dean, M., Lampila, P., Saba, A., Lähteenmäki, L., \& Shepherd, R. (2008). Predicting intentions to purchase organic food: The role of affective and moral attitudes in the Theory of Planned Behaviour. Appetite, 50 (2), 443-454.

8. Bailey, A. A., Bailey, A. A., Mishra, A., Mishra, A., Tiamiyu, M. F., \& Tiamiyu, M. F. (2016). GREEN consumption values and Indian consumers' response to marketing communications. Journal of Consumer Marketing, 33(7), 562-573.

9. Baker, J., \& Ozaki, R. (2008). Pro-environmental products: marketing influence on consumer purchase decision. Journal of consumer marketing, 25(5), 281-293.

10. Beckford, C. L., Jacobs, C., Williams, N., \& Nahdee, R. (2010). Aboriginal environmental wisdom, stewardship, and sustainability: Lessons from the Walpole Island First Nations, Ontario, Canada. The journal of environmental education, 41(4), 239-248.

11. Blake, J. (1999). Overcoming the 'value-action gap' in environmental policy: Tensions between national policy and local experience, Local Environment, 4(3), 257-278.

12. Caruana, R., Carrington, M. J., \& Chatzidakis, A. (2016). "Beyond the AttitudeBehaviour Gap: Novel Perspectives in Consumer Ethics": Introduction to the Thematic Symposium. Journal of Business Ethics, 136(2), 215-218.

13. Chan, R. Y. (2001). Determinants of Chinese consumers' green purchase behavior. Psychology \& Marketing, 18(4), 389-413.

14. Chaplin, G., \& Wyton, P. (2014). Student engagement with sustainability: Understanding the value-action gap. International Journal of Sustainability in Higher Education, 15(4), 404-417.

15. Chen, M. F. (2007). Consumer attitudes and purchase intentions in relation to organic foods in Taiwan: Moderating effects of food-related personality traits. Food Quality and Preference, 18(7), 1008-1021 
16. Chen, M. F., \& Tung, P. J. (2014). Developing an extended theory of planned behavior model to predict consumers' intention to visit green hotels. International journal of hospitality management, 36, 221-230.

17. Chen, Y. S. (2013). Towards green loyalty: driving from green perceived value, green satisfaction, and green trust. Sustainable Development, 21(5), 294-308.

18. Chen, Y. S., \& Chang, C. H. (2012). Enhance green purchase intentions: The roles of green perceived value, green perceived risk, and green trust. Management Decision, 50(3), 502-520.

19. Crosby, L.A., Gill, J.D. \& Taylor, J.R. (1981). Consumer voter behaviour in the passage of the Michigan container law. The Journal of Marketing, 45(2), 19-32.

20. De Leon, I. G., \& Fuqua, R. W. (1995). The effects of public commitment and group feedback on curbside recycling. Environment and Behavior, 27(2), 233-250.

21. do Paço, A. M. F., \& Reis, R. (2012). Factors affecting skepticism toward green advertising. Journal of advertising, 41(4), 147-155.

22. D'Souza, C., Taghian, M., Sullivan-Mort, G., \& Gilmore, A. (2015). An evaluation of the role of green marketing and a firm's internal practices for environmental sustainability. Journal of strategic marketing, 23(7), 600-615.

23. Dunlap, R. E., Van Liere, K. D., Mertig, A. G., \& Jones, R. E. (2000). New trends in measuring environmental attitudes: measuring endorsement of the new ecological paradigm: a revised NEP scale. Journal of social issues, 56(3), 425-442.

24. Eisenberg, N., \& Miller, P. A. (1987). The relation of empathy to prosocial and related behaviors. Psychological bulletin, 101(1), 91 .

25. Ellen, P. S., Wiener, J. L., \& Cobb-Walgren, C. (1991). The role of perceived consumer effectiveness in motivating environmentally conscious behaviors.Journal of Public Policy \& Marketing, 10(2), 102-117.

26. Faff, R. W. (2015). A simple template for pitching research. Accounting \& Finance, 55(2), 311-336.

27. Grimmer, M., \& Miles, M. P. (2017). With the best of intentions: a large sample test of the intention-behaviour gap in pro-environmental consumer behaviour. International Journal of Consumer Studies, 41(1), 2-10.

28. Grimmer, M., \& Woolley, M. (2014). Green marketing messages and consumers' purchase intentions: Promoting personal versus environmental benefits. Journal of Marketing Communications, 20(4), 231-250.

29. Han, H., Hsu, L. T. J., \& Sheu, C. (2010). Application of the theory of planned behavior to green hotel choice: Testing the effect of environmental friendly activities. Tourism management, 31(3), 325-334.

30. Jobber, D. (2007) Principles \& Practice of Marketing, 5th ed. Maidenhead, McGraw-Hill

31. Kim, Y. and S. M. Choi (2005), "Antecedents of Green Purchase Behavior:An Examination of Collectivism, Environmental Concern, and PCE," Advances in Consumer Research, $32(1), 592-599$. 
32. Klöckner, C. A. (2013). A comprehensive model of the psychology of environmental behaviour-A meta-analysis. Global Environmental Change, 23(5), 1028-1038.

33. Koller, M., Floh, A., \& Zauner, A. (2011). Further insights into perceived value and consumer loyalty: A "green” perspective. Psychology \& Marketing, 28(12), 1154-1176.

34. Kotler, P., \& Armstrong, G. (2013).Principles of Marketing 15th Global Edition. Pearson.

35. Kotler, P.,\& Keller, K. L. (2006).Marketing management.12th (ed.). Upper Saddle River, NJ: Pearson Prentice Hall Inc.

36. Kumar, B., Manrai,A. K., \& Manrai, L.A. (2017). Purchasing behaviour for environmentally sustainable products: A conceptual framework and empirical study. Journal of Retailing and Consumer Services, 34, 1-9.

37. Lee, J. A., \& Holden, S. J. (1999). Understanding the determinants of environmentally conscious behavior. Psychology and Marketing, 16(5), 373-392.

38. Lee, K. (2008). Opportunities for green marketing: young consumers. Marketing intelligence \& planning, 26(6), 573-586.

39. Lin, J., Lobo, A., \& Leckie, C. (2017). The role of benefits and transparency in shaping consumers' green perceived value, self-brand connection and brand loyalty. Journal of Retailing and Consumer Services, 35, 133-141.

40. Liobikienè, G., Grincevičienè, Š., \& Bernatonienè, J. (2017). Environmentally friendly behaviour and green purchase in Austria and Lithuania. Journal of Cleaner Production, 142, 3789-3797.

41. Lobler, H. (2017). Humans' relationship to nature-framing sustainable marketing. Journal of Services Marketing, 31(1). 73- 82.

42. López-Mosquera, N., \& Sánchez, M. (2012). Theory of Planned Behavior and the Value-Belief-Norm Theory explaining willingness to pay for a suburban park. Journal of environmental management, 113, 251-262.

43. Martin, D. M., \& Väistö, T. (2016). Reducing the Attitude-Behavior Gap in Sustainable Consumption: A Theoretical Proposition and the American Electric Vehicle Market. In Marketing in and for a Sustainable Society (pp. 193-213). Emerald Group Publishing Limited.

44. Matthes, J., \& Wonneberger, A. (2014). The skeptical green consumer revisited: Testing the relationship between green consumerism and skepticism toward advertising. Journal of advertising, 43(2), 115-127.

45. McCarty, J. A., \&Shrum, L. J. (2001). The influence of individualism, collectivism, and locus of control on environmental beliefs and behavior.Journal of Public Policy \& Marketing,20(1), 93-104.

46. Mei, O. J., Ling, K. C., \& Piew, T. H. (2012). The antecedents of green purchase intention among Malaysian consumers. Asian Social Science, 8(13), 246.

47. Moe, K. (2007). Compelling yet unreliable theories of sustainability. Journal of Architectural Education, 60(4), 24-30.

48. Mostafa, M. M. (2007). Gender differences in Egyptian consumers' green purchase 
behaviour: the effects of environmental knowledge, concern, and attitude. International Journal of Consumer Studies, 31(3), 220-229.

49. Nelson, M. (2016, July). Sustainable Citizenship on the Local Level in Sweden: Towards an Understanding for How to Resolve Tensions Between Social, Economic, and Ecological Sustainability. In Third ISA Forum of Sociology (July 10-14, 2016). Isaconf.

50. Nguyen, T. N., Lobo, A., \& Greenland, S. (2016). Pro-environmental purchase behaviour: The role of consumers' biospheric values. Journal of Retailing and Consumer Services, 33, 98-108.

51. Ohtomo, S., \& Hirose, Y. (2007). The dual-process of reactive and intentional decisionmaking involved in eco-friendly behavior. Journal of Environmental Psychology, 27(2), 117-125.

52. Ottman, J.A., Stafford, E. R., \& Hartman, C. L. (2006). Avoiding green marketing myopia: Ways to improve consumer appeal for environmentally preferable products. Environment: Science and Policy for Sustainable Development, 48(5), 22-36.

53. Pickett-Baker, J., \& Ozaki, R. (2008). Pro-environmental products: marketing influence on consumer purchase decision. Journal of consumer marketing, 25(5), 281-293.

54. Samarasinghe, R . (2012) . Is Social Psychological Model Sufficient: Empirical Research Gaps for understanding Green Consumer Attitudinal Behavior. International Journal of Advanced Research in Management and Social Sciences, 1 (4), 28-54.

55. Schwartz, S. H. (1977). Normative influences on altruism. Advances in experimental social psychology, 10, 221-279.

56. Schwartz, S. H. (1992). Universals in the content and structure of values: Theoretical advances and empirical tests in 20 countries. Advances in experimental social psychology, 25(1), 1-65.

57. Stern, P. C. (2000). New environmental theories: toward a coherent theory of environmentally significant behavior. Journal of social issues, 56(3), 407-424.

58. Thøgersen, J., \& Ölander, F. (2006). To what degree are environmentally beneficial choices reflective of a general conservation stance?. Environment and Behavior, 38(4), 550-569.

59. Warde, A. (2017). Sustainable Consumption: Practices, Habits and Politics. In Consumption (pp. 181-204). Palgrave Macmillan UK.

60. Wei, C. F., Chiang, C. T., Kou, T. C., \& Lee, B. C. (2017). Toward Sustainable Livelihoods: Investigating the Drivers of Purchase Behavior for Green Products. Business Strategy and the Environment.

61. Yadav, R., \& Pathak, G. S. (2016). Young consumers' intention towards buying green products in a developing nation: Extending the theory of planned behavior. Journal of Cleaner Production, 135, 732-739.

62. Zhu, Q., \& Sarkis, J. (2016). Green marketing and consumerism as social change in China: Analyzing the literature. International Journal of Production Economics, 181, 289-302. 